\title{
RITUAL, KEPERCAYAAN LOKAL DAN IDENTITAS BUDAYA MASYARAKAT CIOMAS BANTEN
}

\author{
Ayatullah Humaeni \\ Fakultas Ushuluddin, Dakwah dan Adab IAIN Sultan Maulana \\ Hasanuddin Banten \\ Email: ayataditya@yahoo.com,
}

\section{Abstract}

This article discusses the local beliefs, the characteristics and cultural identity as well as the socio-religious rituals of Ciomas society. It is a field research using ethnographical method based on anthropological perspective. To analyze the data, the researcher uses structural-functional approach. The finding shows the champion character of jawara is frequently identified with negative labels by several authors such as Willams and Kartodirdjo. The fame of Golok Ciomas that has historical and cultural values for Bantenese society in general is also often referred to champion figures who are rude, valiant, and act like a criminal. As a matter of fact, for majority of Bantenese society, such distinctive characteristics have more positive meanings that were inherited by their ancestors and they still possess religious values maintained up to the present.

Artikel ini mengkaji sistem kepercayaan lokal, karakteristik dan identitas kultural masyarakat, serta ritual sosial keagamaan masyarakat Ciomas. Artikel ini merupakan hasil penelitian lapangan dengan menggunakan metode ethnografi dengan menggunakan pendekatan antropologis. Dalam menganalisa data, peneliti menggunakan pendekatan fungsional-struktural. Hasil penelitian menunjukkan bahwa "karakter jawara" seringkali oleh beberapa penulis seperti Williams dan Kartodirdjo digambarkan dengan label-label negatif. Popularitas Golok Ciomas yang memiliki nilai historis dan kultural bagi masyarakat Banten secara umum juga seringkali disandingkan dengan sosok jawara yang terkenal dengan sikapnya yang keras, berani, dan suka berbuat kriminal. Padahal, bagi sebagian besar masyarakat Ciomas sendiri karakteristik-karakteristik khas 
tersebut sebenarnya memiliki makna yang lebih positif yang diwariskan oleh nenek moyang dan masih memiliki nilai-nilai religius yang masih dipertahankan hingga saat ini.

Keywords: Ritual, Local Beliefs, Cultural Identity

\section{Pendahuluan}

Masyarakat Ciomas Banten seringkali dipandang sebagai masyarakat yang memiliki watak keras dan berjiwa jawara. Seringkali ketika menyebut nama Ciomas, orang akan menghubungkannya dengan Golok Ciomas, jawara, keras, berani, bacokan, dan tindakan kekerasan lainnya. Konotasi negatif terhadap orang Ciomas yang masih melekat sampai saat ini tentu saja bukan tanpa alasan atau tanpa sebab.

Namun demikian, tingkat religiusitas masyarakat Ciomas juga menjadi citra positif yang cukup melekat dalam pandangan orang luar. Hal ini terindikasi dari banyaknya pesantren, kiai, dan ahli hikmah yang memiliki popularitas cukup luas, baik dalam hal tingkat keilmuan (Islam) maupun dalam hal kemampuan ilmu hikmah (magis), dalam pandangan orang luar. Citra positif yang melekat pada tokoh-tokoh agama dan ahli magis ini menjadi magnet bagi masyarakat luar, baik yang berasal dari daerah Banten maupun luar Banten, untuk belajar agama, meminta ilmu hikmah (magis) untuk beragam tujuan pragmatis, maupun yang hanya sekedar sowan (silaturahmi) dan meminta doa restu kepada kiai dan ahli hikmah di Ciomas Banten.

Karakteristik-karakteristik masyarakat Ciomas yang penulis uraikan di atas tentu menjadi fenomena menarik bagi sebagian orang yang belum mengenal dan memahami dengan baik identitas kultural masyarakat Ciomas. Di satu sisi, label negatif sulit terhapus dari image masyarakat Ciomas dalam pandangan orang luar. Di sisi yang lain, banyaknya pesantren dan figur-figur karismatik yang menjadi pemimpin tradisional masyarakat Ciomas dengan kemampuan ilmu agama dan ilmu magisnya menjadi penyeimbang dalam pencitraan identitas masyarakat Ciomas. Berbagai ritual keagamaan dan tradisi adat yang bersandar pada nilai-nilai keagamaan yang rutin dilakukan setiap tahun juga memperlihatkan adanya fenomena keagamaan yang menarik yang menjadi bagian dari identitas kultural masyarakat Ciomas. Oleh karena itu, makalah ini mencoba menjelaskan: bagaimana sistem religi masyarakat Ciomas?; bagaimana karakteristik dan identitas kultural masyarakat Banten?; dan bagaimana bentuk ritual dan tradisi sosial keagamaan masyarakat Ciomas? 


\section{Metode Penelitian}

Artikel ini merupakan hasil penelitian lapangan dengan menggunakan metode penelitian ethnografi yang bersifat deskriptif kualitatif. Ethnografi merupakan pekerjaan mendeskripsikan suatu kebudayaan. Tujuan utama etnografi adalah memahami sudut pandang penduduk asli, hubungannya dengan kehidupan, untuk mendapatkan pandangannya mengenai dunianya. Selanjutnya, etnografi bermakna untuk membangun suatu pengertian yang sistemik mengenai semua kebudayaan manusia dari perspektif orang yang telah mempelajari kebudayaan tersebut.

Metode yang digunakan untuk mengumpulkan data adalah kajian pustaka, observasi terlibat, dan wawancara mendalam. Dalam menganalisa data, peneliti menggunakan pendekatan fungsional-struktural (structural-functional approach) yang merupakan suatu pandangan tentang sistem sosio-kultural yang menekankan bahwa struktur-struktur yang diamati menunjukan fungsi-fungsi dalam struktur tertentu atau struktur itu menunjukan fungsi dalam sistem yang lebih luas.

\section{Hubungan Religi dan Budaya}

Ada dua pandangan besar mengenai hubungan antara kebudayaan dan religi. Pandangan pertama adalah yang menyatakan bahwa kebudayaan merupakan bagian dari religi; sedangkan pandangan kedua menyatakan religi adalah bagian dari kebudayaan. Pandangan pertama, tidak bisa dipahami oleh mereka yang berusaha menjelaskan segala fenomena yang menyangkut hidup manusia secara kognitif. Sebaliknya pandangan kedua adalah tidak akseptabel bagi mereka yang percaya bahwa hidup manusia adalah realisasi dari wahyu, yang tidak mensyaratkan pengertian (Kusumohamidjojo, 2010: 219).

Dalam semua konteks budaya lintas dunia, agama adalah bagian integral dalam aspek-aspek aktifitas budaya yang lain. Agama adalah apa yang orangorang lakukan dari hari ke hari. Dengan kata lain, agama menjadi seperangkat ide gagasan dan kepercayaan dimana setiap orang bisa terlibat, dan juga sebagai kerangka bagi pengalaman hidup dan aktifitas keseharian mereka. Mengkaji agama dan budaya selanjutnya adalah memahami bagaimana agama menjadi elemen penting yang memanifestasikan perbedaan-perbedaan mereka. Hal ini berarti bahwa mengkaji agama bersifat komparatif, atau lebih tepatnya mengkaji agama adalah lintas budaya, melihat agama-agama melintasi daerah dari budaya yang berbeda-beda (Nye, 1992: 3). 
Terkait penyebutan agama dan religi, Harsojo (1984) adalah tipe ahli antropologi yang tidak hendak terlibat dalam polemik itu dengan cara menjelaskan cara pandangnya terhadap religi. Pertama, ia lebih suka menggunakan istilah 'religi' ketimbang 'agama', karena istilah 'agama' menurutnya sudah memiliki arti tertentu yang spesifik seperti 'agama Islam atau agama Nasrani'. Harsojo juga lebih suka menggunakan istilah 'religion' ketimbang 'confession' sebagai istilah yang hendak merangkum sistem kepercayaan manusia sebagai suatu fenomena umum. Kedua, dijelaskannya bahwa antropologi menyelidiki religi secara empiris dan komparatif untuk memahami asal-usul religi, fungsi religi, dan sistematika religi. Antropologi tidak menyelidiki kebenaran dalam religi, melainkan menyelidiki pengaruh agama itu pada manusia dan masyarakat serta pengaruhnya pada perkembangan kebudayaan. Religi merupakan bagian dari kebudayaan manusia, oleh karenanya kedua pendekatan itu (teologi dan antropologi) tidak perlu saling bertentangan (Harsojo, 1984: 220-221).

Menurut Leslie A. White, religi atau salah satu unsur yang membentuk religi yakni keyakinan (belief), adalah salah satu bagian dari sistem ideologis. Sistem ini sendiri adalah salah satu wujud inti kebudayaan. Dengan demikian religi adalah bagian dari dan terbentuk dalam ruang lingkup kebudayaan manusia (dalam Radam, 2001: 2).

Dalam kajian ini, penulis memahami religi bukan semata-mata sebagai agama, melainkan sebagai fenomena kultural. Religi adalah wajah kultural suatu bangsa yang unik. Religi adalah dasar keyakinan, sehingga aspek kulturalnya sering mengapung di atasnya. Hal ini merepresentasikan religi sebagai fenomena budaya universal. Religi adalah bagian budaya yang bersifat khas. Menurut Malinowski (1954: 17), tidak ada seorang pun di dunia ini, seprimitif apa pun orang tersebut, yang tidak beragama dan tidak mempercayai magis. Pernyataan ini dikemukakan berdasarkan data dan fakta bahwa sudah banyak penelitian-penelitian yang dilakukan terkait dengan kepercayaan dan religi masyarakat primitif di berbagai belahan dunia. Dalam alam pikiran mereka, ada suatu kepercayaan terhadap sesuatu yang suci (the sacred), di samping sesuatu yang dianggap biasa (the profane). Dua domain ini tidak pernah bisa lepas dari alam pikiran manusia. Domain the sacred muncul dan hadir dalam bentuk kepercayaan terhadap magis dan agama, dan domain the profane menampakkan diri dan berkembang menjadi science. Artinya bahwa, seprimitif apapun sebuah masyarakat, selalu dalam gagasannya tidak terlepas dari dua domain tersebut. 
Konsep religi mengandung berbagai unsur seperti keyakinan, ritual, upacara, sikap dan pola tingkah laku, serta alam pikiran dan perasaan para penganutnya. Berbagai aktifitas seperti berdo'a, bersujud, bersaji, berkorban, slametan, makan bersama, menari dan menyanyi, berprosesi, berseni drama suci, berpuasa, bertapa, bersemedi, mengucapkan mantra, mempraktikan magis, mempercayai mahluk-mahluk halus (gaib), menyediakan sesajen dan lain sebagainya merupakan bagian dari aktifitas religi (Koentjaraningrat, 1980 : 81). Aktifitas inilah yang membuat sebuah kepercayaan menjadi suatu religi.

\section{Sistem Religi Masyarakat Ciomas Banten}

Banten merupakan daerah yang pernah menjadi salah satu pusat perdagangan internasional dan kesultanan Islam paling kuat di Nusantara. Masyarakatnya yang disebut-sebut dalam catatan Snouck Hugronje sebagai masyarakat muslim yang lebih sadar diri dan lebih taat dalam menjalankan ajaran agama dibandingkan dengan daerah lainnya di pulau Jawa, menjadikan citra Banten sebagai daerah yang religius. Bahkan, masih dalam catatan Snouck Hugronje, pada akhir abad ke-19, orang-orang Banten merupakan orang-orang yang sangat menonjol di antara orang-orang Asia Tenggara yang menetap di Makkah, baik sebagai guru maupun murid (Hakim, 2006: 83; Ali, 2012: 1617; Bruinessen, 1995: 246).

Citra positif yang melekat pada masyarakat Banten ini tentu tidak lepas dari peran para penguasa (Sultan) Banten saat itu yang tidak hanya concern dalam bidang politik dan ekonomi, tetapi juga memberikan perhatian lebih dalam bidang keagamaan. Dalam catatan Martin van Bruinessen, dikatakan bahwa untuk memperkuat dan mengembangkan bidang keagamaan, Sultan Banten mengundang para ulama Nusantara dan ulama dari Timur Tengah, khususnya Mekkah, untuk datang dan menetap selama jangka waktu tertentu di Banten. Mereka mengajarkan ilmu-ilmu agama kepada masyarakat. Hubungan baik yang terjalin antara Kesultanan Banten dengan Mekkah sebagai pusat dan kiblat keislaman dunia turut membangun peradaban Islam yang cukup kuat di Banten. Untuk memperoleh legitimasi keagamaan, beberapa Sultan Banten meminta gelar "Sultan" kepada Syarif di Mekkah. Gelar inilah yang menjadikan para Sultan Banten dipandang bukan hanya sebagai penguasa negeri, tapi juga secara absah dianggap sebagai pemimpin agama (ulama/wali). Kesultanan Banten menunjukkan kecintaan dan perhatian yang besar kepada ilmu agama, juga penghargaan serta penghormatan yang tinggi terhadap para ulama. Oleh karena itu, dalam beberapa catatan yang ditulis oleh orang 
Eropa yang pernah berkunjung ke kesultanan Banten pada abad ke-16 dan 17, disebutkan bahwa kesultanan Banten menjadi pusat kegiatan keilmuan Islam di Nusantara (Bruinessen, 1995: 247-248).

Meskipun Islam menjadi simbol peradaban baru bagi masyarakat Banten sejak masa kesultanan, namun para Sultan Banten tidak serta merta menghapus jejak tradisi dan budaya lokal Banten yang sudah ada jauh sebelum Islam masuk dan berkembang di Banten. Indikasi bahwa penguasa Banten saat itu masih menghargai dan menghormati tradisi dan budaya lokal adalah cerita dalam 'Sadjarah Banten' yang menyatakan bahwa Sultan Agung Tirtayasa, sejak belia dan masih menjabat sebagai Sultan Muda, dikenal sebagai putra bangsawan yang sangat menyukai kebudayaan. Bahkan ia seringkali terlibat aktif dalam beberapa tradisi permainan rakyat Banten seperti permainan raket (semacam wayang wong), dedewaan, sasaptoan, dan berbagai tradisi lokal lainnya (Tjandrasasmita 2011: 29). Ini mengindikasikan bahwa Sultan Banten, yang dianggap sebagai pemimpin agama, ulama, bahkan wali, tidak pernah berusaha menghapus jejak tradisi dan budaya lokal yang dianggap tidak merusak aqidah umat Islam. Bahkan dalam beberapa hal, mencoba menjadikan beragam tradisi dan budaya lokal sebagai media dakwah dalam menyebarkan Islam kepada penduduk Banten yang sebelumnya masih banyak yang menganut kepercayaan animisme, dinamisme, Hindu dan Budha (Michrob \& Chudari 2011: 19-46; Lubis 2004: 1-24; Lubis 2006: 2-13).

Berkaitan dengan kitab-kitab Allah, masyarakat Ciomas, sebagaimana yang dinyatakan oleh K.H. Anas Albandanidji (2011), memahami bahwa Allah pernah menurunkan kitab-kitab suci sebelum al Quran, yaitu Zabur, Taurat, dan Injil. Namun demikian, menurut Mashadi (2011), hanya al Quran kitab suci yang masih terjaga kesucian dan kemurniannya, dan al Quran adalah penyempurna dari kitab-kitab sebelumnya. Pemahaman seperti ini nampaknya juga diyakini oleh seluruh Muslim Indonesia, bahkan dunia. Dalam hal ini, Nurkholis Madjid berpendapat bahwa tidak ada seorang Muslim pun di dunia yang meragukan keaslian dan keabsahan kitab sucinya. Menurut kepercayaan Islam, al Quran adalah pegangan hidup terakhir dari yang diwahyukan Allah kepada umat manusia melalui perantaraan Nabi Muhammad SAW sebagai penutup para Nabi dan Rasul (Madjid, 2000: 3).

Dalam hal hari akhir atau hari kiamat, masyarakat Ciomas meyakini bahwa akan ada hari akhir dan hari pembalasan setelah dunia ini mengalami kehancuran. Keyakinan yang terakhir yang dipahami oleh masyarakat Ciomas dan bersumber dari al Quran adalah keyakinan akan Qadha dan Qadhar 
Tuhan. Dalam hal ini, Ibu Een berpendapat bahwa segala hal di dunia ini terjadi atas kehendak Allah, tidak ada seorang pun yang bisa menolak takdir Allah (2011).

\section{Konsepsi tentang Magis, Alam Gaib dan Makhluk Halus}

Kepercayaan terhadap dunia gaib dan praktek ilmu magis sepertinya bisa ditemukan di banyak wilayah di Indonesia seperti Jawa. Dalam hal ini, O'Keefe (1982: 1) berpendapat bahwa kepercayaan terhadap magis tidak hanya ditemukan pada zaman batu dan pada masyarakat primitif saja, tapi juga bisa ditemui di hampir setiap masa.

Zainuri dan sebagian besar masyarakat Ciomas meyakini bahwa selain menciptakan manusia, hewan, tumbuh-tumbuhan dan segala yang ada di alam, Tuhan juga menciptakan makhluk lain yang tidak bisa dilihat dengan mata telanjang manusia (2011). Berkaitan dengan jin, Bapak Ai, seorang dukun, meyakini bahwa tidak semua jin itu jahat, ada jin yang baik atau sering disebut juga jin Islam, ada juga jin yang jahat atau jin kafir yang selalu mengganggu manusia (2011). Hantu, iblis, setan, dedemit dan sejenisnya adalah mahklukmakhluk gaib atau jin-jin jahat yang hidupnya diabdikan untuk menganggu kehidupan manusia. Namun demikian, sebagian mereka meyakini bahwa manusia bisa berhubungan dengan makhluk gaib ini. Ust. Rhmn, misalnya, meyakini bahwa meskipun manusia tidak bisa melihat jin atau makhlukmakhluk gaib lainnya, tapi mereka bisa berhubungan dengan makhluk-makhluk supranatural itu secara spiritual melalui ritual-ritual dan formula-formula tertentu (2011). Bahkan, menurut K.H.F, jika berhasil, mereka yang mampu berkomunikasi dengan makhluk-makhluk supranatural melalui komunikasi gaib itu, bisa menundukkan makhluk-makhluk itu bahkan memerintahkannya untuk melakukan perintah-perintahnya (2011). Orang-orang yang memiliki kemampuan ini seringkali diminta untuk memecahkan masalah-masalah praktis manusia melalui kemampuan magisnya.

Dalam kehidupan ekonomi, banyak sekali para pedagang, pengusaha, maupun yang bekerja di instansi pemerintahan dan di perusahaan, juga memanfaatkan magis sebagai bagian dari usaha mereka memperoleh rejeki yang berlimpah serta memperoleh jabatan tertentu. Kedatangan mereka ke para ahli magis, dengan beragam tujuan dan kepentingan, menunjukan betapa masyarakat Ciomas masih menggantungkan kesuksesan dan kelancaran perekonomian mereka pada hal-hal yang gaib. Selanjutnya, aspek kehidupan lain yang juga sering melibatkan kemampuan magis para ahli magis adalah 
aspek kesehatan. Masyarakat Ciomas secara khusus masih percaya bahwa penyakit-penyakit tertentu, baik penyakit jasmaniah maupun penyakit yang disebabkan oleh kejahatan magis, dapat diobati dengan cara-cara magis maupun dengan do'a-do'a tertentu dari para kyai. Berkaitan dengan fungsi magis dalam pengobatan, Bapak H. Ry (64 thn) menuturkan bahwa berbagai pengobatan medis yang dijalaninya untuk mengangani penyakit strokenya tidak berhasil sehinga ia menjalani pengobatan ke ahli hikmah. Setelah menjalani tiga kali pengobatan dengan ahli hikmah yang menempelkan uang logam ke tubuhnya sambil dibacakan mantra, kondisinya berangsur membaik (2011).

Dari penuturan Bapak H. Ry tersebut, kita juga bisa menyimpulkan bahwa dalam hal kesehatan, sebagian masyarakat Ciomas masih percaya bahwa kekuatan magis dari para kyai, ahli hikmah, dan dukun juga bisa melakukan pengobatan dan hasilnya nampak lebih efektif dan lebih cepat dirasakan oleh pasien. Pengalaman-pengalaman empiris semacam inilah yang barangkali membuat budaya magis masih mendapat tempat dalam budaya masyarakat Ciomas. Oleh karenanya, daerah Ciomas seringkali menjadi salah satu tempat tujuan pengobatan alternatif bagi para pasien dengan beragam jenis penyakit. Hasil pengamatan peneliti di salah satu pesantren salafi (pesantren tradisional) di Ciomas, berkali-kali peneliti datang ke pesantren tersebut, setiap hari selalu saja ada orang yang datang membawa pasien yang sakit ke rumah kiai, baik yang datang dari daerah Ciomas, maupun dari luar kota dan luar daerah Banten. Do'a dari kiai serta air putih yang sudah dibacakan doa oleh kiai menjadi harapan besar bagi para pasien dan keluarganya untuk kesembuhan penyakit si pasien. Sugesti yang begitu besar dengan kekuatan doa dan kekuatan magis kiai menjadi faktor penting bagi kesembuhan pasien.

Fenomena tersebut menunjukkan bahwa kepercayaan terhadap magis adalah sebuah fenomena sosial yang ada baik pada masyarakat tradisional maupun masyarakat modern, tidak terkecuali pada masyarakat Ciomas Banten. Karenanya hampir sebagian besar masyarakat Ciomas percaya bahwa magis itu betul-betul ada dan terjadi dalam area kehidupan mereka dan mereka percaya bahwa situasi-situasi sosial bisa dipengaruhi, diubah, disembuhkan, dihancurkan dan ditransformasikan dengan tindakan-tindakan magis. Dalam hal ini, magis bisa membangun kepercayaan dalam situasi-situasi yang tidak pasti (Malinowski, 1955: 79).

Pendapat Malinowski juga dapat dijadikan sandaran mengapa dalam banyak aspek sosial-keagamaan, sebagian masyarakat di Ciomas Banten masih meyakini kepercayaan dan praktik magis dan cenderung menyelesaikan masalah- 
masalah praktis yang mereka temui dalam kehidupan sehari-hari dengan bersandar kepada ahli-ahli magis dan kekuatan supranatural mereka. Dalam hal ini, K.H.F. menuturkan adanya banyak warga yang menemuinya untuk mengatasi berbagai masalah mereka. Ilmu hikmah (magis) yang dimilikinya juga tidak keluar dari Islam karena bersumber dari kitab Arab klasik seperti Mamba' Ushul al-Hikmah karya al-Buni (2011).

Apa yang diceritakan oleh K.H.F. di atas, tentu saja tidak dapat dilepaskan dari kepercayaan masyarakat yang masih tinggi atas kekuatan gaib yang dianggap mampu membantu mewujudkan harapan dan keinginan mereka atas kondisi yang tidak menentu tersebut. Selanjutnya Malinowski berpendapat bahwa sebagaimana agama, magis juga muncul dan berfungsi dalam situasi-situasi emotional stress seperti dalam kondisi krisis, dalam kondisi kosong atau hampa karena mengejar sesuatu yang dianggap penting, kehidupan cinta yang tidak bahagia dan kebencian (Malinowski, 1955: 87). Berbagai persoalan hidup yang ditemui oleh masyarakat di desa Ciomas Banten seperti penyakit yang tidak kunjung sembuh, baik penyakit fisik, psikis, maupun penyakit yang dianggap berasal dari black magic. Sebagian contohnya seperti teluh, tenung, santet, gunaguna; depresi karena ditolak cinta, sulit jodoh, sulit mendapatkan pekerjaan, ingin cepat kaya, dan persoalan-persoalan hidup lainnya adalah faktor-faktor penyebab emotional stress yang menyebabkan mereka tidak lagi bisa berfikir rasional. Pada akhirnya mereka lebih memilih menyelesaikan masalah mereka dengan cara cepat dan praktis yaitu dengan mendatangi ahli-ahli magis.

Dalam kehidupan sosial dan politik, baik di tingkat lokal, daerah, maupun nasional, sebagian masyarakat Ciomas masih mempercayai para kiai hikmah dan dukun untuk mencapai kedudukan sosial dan prestise sosial. Dalam hal pemilihan kepala desa, misalnya, hampir seluruh calon kepala desa di Ciomas mendatangi ahli-ahli magis untuk membantu mereka memenangkan Pilkades. Ada beragam alasan yang menyebabkan mereka lebih memilih cara-cara halus dengan menggunakan magis untuk tujuan pemenangan Pilkades ini. Pertama, mereka melakukannya sebagai tindakan preventive atas tindakan yang sama yang dilakukan oleh calon-calon kepala desa yang lain. Kedua, mereka tidak merasa percaya diri. Ketiga, karena dorongan atau saran dari keluarga, saudara, maupun para pendukung; keempat, tindakan itu sebagai bagian dari ikhtiar (usaha atau upaya) yang bersifat batiniah karena menurut mereka Islam juga menganjurkan manusia untuk tidak hanya berupaya secara lahiriah, tetapi juga secara batiniah dengan cara mendatangi kiai, ahli hikmah, dukun atau wong pinter (Humaeni, 2009: 45). 
Oleh karena kepercayaan terhadap hal gaib tersebut, praktek-praktek magis baik yang dilakukan oleh ahli hikmat atau kyai hikmat, maupun oleh dukun dan wong pinter masih banyak ditemukan di daerah Ciomas. Kyai, bagi masyarakat Ciomas, tidak hanya dipandang sebagai figur yang menguasai ilmu-ilmu agama, tetapi juga memiliki kemampuan magis yang bersumber dari agama melalui formula-formula dan ritual-ritual tertentu, yang dipergunakan untuk menyelesaikan dan membantu masalah dan kebutuhan praktis manusia. Selanjutnya, dukun atau wong pinter yang juga dianggap memiliki kemampuan dalam hal menundukan kekuatan makhluk gaib atau roh jahat melalui formula dan ritual magisnya juga menempati tempat khusus bagi masyarakat Ciomas dalam memecahkan persoalan-persoalan hidup mereka.

Namun, masyarakat Ciomas yakin bahwa di atas semua jenis makhluk gaib itu ada kekuatan yang jauh lebih besar, lebih kuat dan lebih tinggi, yaitu kekuatan Tuhan. Sehebat dan sekuat apapun kemampuan para ahli magis, mereka selalu menyandarkan hasil dari ilmu yang mereka miliki kepada kekuatan dan kekuasaan Tuhan. Dalam hal ini, K.H. Maksum berpendapat bahwa hanya Allah lah yang mampu menyembuhkan, mampu memberi rizki, memberi jodoh, dan mampu melakukan apapun, bahkan yang tidak bisa dan tidak mungkin dilakukan oleh manusia maupun makhluknya yang lain sekalipun (2011).

Di samping keyakinan atas beragam praktik magis tersebut di atas, ternyata gagasan tentang adanya roh-roh halus, jin, setan dan sejenisnya dalam pikiran masyarakat Ciomas juga masih bertahan hingga saat ini. Dalam pandangan masyarakat Ciomas, ada beberapa jenis hantu atau setan yang mengganggu manusia dan serngkali menampakkan diri dihadapan manusia. Ibu Tati, misalnya, menuturkan mengenai keberadaan keong wewe atau hantu pengganggu yang menculik gadis yang setelah diketemukan terlihat seperti orang gila karena suka berbicara sendiri. Selain cerita tentang kelong wewe tersebut di atas, ada kepercayaan terhadap jenis-jenis hantu atau setan yang lain seperti gogodan, bebongkong, pocong, kuntilanak, tuyul, wewe gombel, Nyi Artati, siluman, babi ngepet dan lain sebagainya (2011).

Keyakinan masyarakat Ciomas terhadap hal-hal yang bersifat supranatural nampaknya menjadi gejala umum di berbagai tempat di seluruh dunia. Ada banyak kajian di berbagai tempat di seluruh dunia yang mengkaji tentang malaikat, jin, hantu, makhluk gaib, maupun makhluk-makhluk supranatural lainnya yang dianggap memiliki kekuatan luar biasa. Gagasan tentang supranatural being ini hampir selalu muncul di setiap agama dan kepercayaan, 
baik pada masyarakat modern maupun masyarakat pre-literate, dan ada di hampir setiap budaya dan era. Nampaknya, kepercayaan terhadap Yang Gaib ini menjadi bagian penting dalam sistem kepercayaan manusia. Oleh karena itu, Rudolf Otto, seorang ahli teologi, berpendapat bahwa semua sistem religi, kepercayaan dan agama di dunia berpusat kepada suatu konsep tentang hal yang gaib (mysterium) yang dianggap maha dahsyat (tremendum), dan keramat (sacer) oleh manusia (dalam Pritchard 1984: 49-50)

Dalam hal ini, Spencer (1876 : 281) berpendapat bahwa keyakinan kepada hantu telah membentuk dasar konsep tentang supranatural yang paling awal. Konsepsi 'ada' makhluk supranatural pertama yang dapat ditelusuri, menurutnya, adalah konsepsi tentang hantu meskipun konsepsi ini mungkin tidak jelas dan berbeda-beda di antara komunitas-komunitas yang menyandarkan hidupnya dengan berburu dan mengumpulkan makanan. Konsepsi ini, menurut Morris (2007: 117), adalah penjelasan rasional yang didasarkan pada penyimpulan dari peristiwa-peristiwa dan fenomena yang tidak terpahami. Gagasan tentang penjelasan yang bersifat natural hanya berkembang dalam masyarakat yang lebih kompleks. Ide tentang hantu kemudian berkembang menjadi ide tentang Tuhan, hantu-hantu dari masyarakat yang terpencil atau nenek moyang yang dianggap penting kemudian memiliki sifat ketuhanan, dan persembahan yang diletakkan di tempat-tempat keramat menjadi dasar bagi adanya upacara ritual. Oleh karenanya, Spencer (876: 411) berpendapat bahwa 'penyembahan terhadap leluhur merupakan akar bagi setiap agama'. Dalam hal ini, Fischer (1980: 137-145) menyebut kepercayaan terhadap setan, roh nenek moyang, jimat, dan makhluk-makhluk gaib lainnya sebagai 'religi rakyat' atau 'religi kerakyatan' yang memiliki corak sinkretis.

Nampaknya bahwa pemikiran mistis dan magis selalu akan memiliki tempat dalam dimensi kehidupan manusia karena dalam alam pemikiran manusia, ada satu ruang mistis dan magis yang sewaktu-waktu dapat muncul ketika manusia berhadapan dengan kondisi-kondisi yang sulit di atasi dengan alam pemikiran rasional mereka. Kecendrungan untuk mengatasi beragam persoalan praktis manusia bukan muncul belakangan setelah manusia menemukan beragam masalah yang kompleks, tetapi dimensi ini memang sudah ada dan sudah tercipta dalam alam pemikiran manusia, di samping alam pemikiran rasional. Oleh karenanya, manusia selalu melakukan, yang dalam istilah Elliade, 'the eternal return' (gerak kembali ke Yang Abadi/yang gaib/ supranatural) (Elliade, 1974: 112-115; Susanto 1987: 64-70). 


\section{Identitas dan Karakteristik Masyarakat Ciomas}

Setiap masyarakat memiliki identitas dan karakteristik budayanya masingmasing. Perbedaan itu bisa nampak dari bahasa yang digunakan, tradisi yang diwariskan, maupun dari budaya yang membentuk pergaulan dan interaksi antar anggota masyarakat. Untuk memahami budaya suatu suku bangsa dengan benar, maka kita harus mengerti tentang seluk-beluk masyarakatnya, dan sebaliknya untuk mendapatkan wawasan yang luas tentang masyarakat, kita harus memahami hakekat kebudayaan dari masyarakat tersebut (Harsojo, 1984: 126).

Identitas dan karakteristik suatu masyarakat akan nampak mudah diamati, dianalisa, dan disimpulkan oleh orang lain yang tinggal di luar daerah. Berikut adalah beberapa karakteristik yang melekat pada ciri masyarakat Ciomas secara umum:

\section{Karakter keras dan berani}

Dalam pandangan masyarakat luar, orang Ciomas sangat dikenal dengan keberanian dan wataknya yang keras. Seringnya orang Ciomas terlibat bentrokan baik dengan sesama warga Ciomas maupun dengan warga dari daerah lain, menjadikan image masyarakat Ciomas sebagai orang yang dikenal berwatak keras dan berani.

\section{Jawara}

Sudah menjadi pengetahuan umum bahwa Banten dikenal sebagai sarangnya para jawara. Berbagai pemberontakan dan kerusuhan sejak zaman kolonial, sampai zaman kemerdekaan melibatkan para tokoh jawara dalam menentang penjajahan di daerah Banten. Keberadaan mereka di satu sisi menjadi kebanggaan bagi masyarakat Banten karena mereka diangap sebagai penolong dan pembela warga, namun di sisi lain aksi-aksi mereka yang seringkali anarkis. Jadi, ada dualisme karakter yang diperankan oleh 3. Jawara di Banten.

Terkait tentang hubungan para jawara Ciomas Banten dengan kiai, menurut informasi dari beberapa informan, nampak bahwa para jawara Ciomas Banten sangat hormat dan melindungi para kyai di Ciomas. Nampaknya, apa yang dijelaskan oleh Tihami dalam studinya mengenai kyai dan jawara memiliki kesamaan dengan apa yang terjadi di Desa Ciomas bahwa kyai adalah sumber kepemilikan magis bagi jawara. Oleh karenanya, tabu bagi jawara untuk membantah apalagi melawan kyai. Jika mereka berani melawan kyai, maka akibatnya akan mendapat kuwalat, yakni hukuman bagi yang melawan kyai dengan akibat hilangnya segala kekuatan magis (Tihami, 1992: 21). 


\section{Golok Ciomas}

Golok Ciomas adalah salah satu peninggalan budaya yang memiliki nilai sejarah dan cerita mistis. Senjata tradisional ini menjadi kebanggaan masyarakat Banten secara umum, dan secara khusus bagi masyarakat Ciomas. Popularitas Golok Ciomas bukan hanya dikenal oleh warga Banten, tapi juga di seluruh Nusantara, karena menurut cerita, Golok Ciomas ini sudah digunakan oleh masyarakat Banten sejak zaman kesultanan, dan berlanjut sampai masa penjajahan.

Bagi masyarakat Banten secara umum, Golok Ciomas diyakini memiliki nilai mistis sebagaimana halnya keris bagi masyarakat Jawa. Golok ini dibuat secara khusus dengan ritual khusus dan dilakukan pada waktu-waktu tertentu. Oleh karenanya, Golok Ciomas asli diyakini sebagai senjata yang ampuh dan memiliki kekuatan magis yang luar biasa untuk melumpuhkan musuh. Bahkan, menurut cerita yang berkembang di masyarakat, musuh dapat dengan mudah ditaklukkan dengan menggunakan golok ini tanpa harus mengeluarkannya dari serangka-nya. Keistimewaan yang lain yang dimiliki oleh Golok Ciomas ini adalah daya magisnya dan kekuatan racunnya yang sulit disembuhkan jika seseorang terluka karena sayatan atau tebasan golok ini. Bahkan, pohon pisang yang terkena sayatan golok ini akan mati membusuk (Solikhin \& Supriyatna 2003: 3-7).

Tindak kekerasan dan sikap berani sekelompok orang tertentu dengan berbagai latar belakang kondisi sosial budaya sebenarnya dimiliki oleh banyak masyarakat di berbagai daerah baik di Indonesia maupun di negara lain. Istilah jago, jawara, pendekar, bandit dan lain sebagainya merupakan istilah-istilah yang hampir merujuk ke sekelompok orang tertentu yang memilki keberanian lebih dan seringkali melakukan berbagai aktifitas fisik atau kekerasan baik untuk hal-hal yang dianggap benar maupun karena hal-hal sepele. Kekerasan itu sendiri memiliki banyak makna bagi pelakunya. Kiefer, sebagaimana dikutip oleh Wiyata, misalnya, menyatakan bahwa tindakan kekerasan, bagi suku Tausug di Filipina, memilki makna kejantanan dan keberanian. Hal ini dikarenakan keberanian merupakan suatu perilaku budaya yang mempunyai makna simbolik tentang nilai dasar dari harga diri dan kehormatan laki-laki suku Tausug, maka tindakan kekerasan yang dilakukan oleh masyarakat Tausug tersebut merupakan suatu prilaku budaya yang memperoleh legitimasi dari lingkungan masyarakatnya. Dalam konteks ini, setiap tindakan kekerasan merupakan refleksi simbolik dari nilai-nilai budaya masyarakat yang harus dipahami maknanya (Wiyata, 2006 : 17). Dengan demikian, tindakan 
kekerasan dan sikap berani yang ditunjukan oleh masyarakat Ciomas juga perlu dipahami sebagai refleksi simbolik dari nilai-nilai dasar masyarakat yang harus dipahami maknanya.

\section{Ritual dalam Tradisi Sosial Keagamaan Masyarakat Ciomas}

Sebagai masyarakat yang seluruh penduduknya beragama Islam, masyarakat Ciomas tidak hanya mengenal, memahami dan mempraktikkan ritual ibadah kepada Tuhan sebagaimana diajarkan dalam al Quran dan hadits, tetapi juga melakukan beragam ritual sosial keagamaan sebagai bagian dari tradisi masyarakat setempat. Ada beberapa ritual sosial keagamaan yang rutin dilakukan setiap tahun oleh masyarakat Ciomas Banten, yaitu:

\section{Upacara Hari Besar Islam}

Dalam kalender Islam, ada beberapa tanggal yang dijadikan sebagai momen Perayaan Hari Besar Islam (PHBI). Ada beberapa upacara atau slametan yang dilakukan oleh masyarakat Muslim di Indonesia, tak terkecuali di daerah Ciomas Banten dalam menyambut dan merayakan Hari Besar Islam tersebut. Di daerah Ciomas, masyarakat biasanya melakukan ritual slametan tertentu untuk menyambut dan merayakan hari Besar Islam, di antaranya:

\section{Bulan Muharam}

Pada bulan Muharam, tepatnya tanggal 10 Muharam atau lebih dikenal dengan 10 Syura, masyarakat Ciomas melakukan ritual Slametan Tolak Bala. Pada tanggal ini, setiap rumah biasanya dimintai beras seikhlasnya. Beras ini kemudian dikumpulkan dan dibuat 'bubur Syuro' (bubur nasi dan sedikit garam, untuk selanjutnya dimakan bersama seluruh warga (ngeriung) sambil membaca do'a selamat.

\section{Bulan Syafar}

Bulan Syafar dikenal sebagai bulan dimana Allah menurunkan berbagai macam penyakit ke dunia. Oleh karena itu, pada bulan ini juga diadakan ritual atau Slametan Talak Bala yang lebih dikenal dengan sebutan Rebo Wekasan. Kegiatan ini biasanya dilakukan pada hari Rabu minggu terakhir di bulan Syafar dengan melakukan salat Talak Bala secara berjamaah di masjid atau musholla. Pada hari inilah orang-orang tua biasanya tidak diperbolehkan anakanak mereka bepergian jauh, karena dikhawatirkan mendapat kecelakaan atau musibah.

4. Bulan Mulud

Bulan Mulud atau lebih dikenal dengan bulan Rabiul Awal, tepatnya pada tanggal 12 Bulan Mulud, diperingati sebagai hari kelahiran Nabi Muhammad 
SAW. Acara ini umumnya dirayakan secara besar-besaran seperti Hari Raya Idul Fitri. Di daerah Ciomas, acara panjang Mulud ini dikenal dengan sebutan "Ngalaha". Dalam kegiatan yang sangat meriah ini, seluruh panjang Mulud dibawa ke Musholla atau Masjid setelah diarak, untuk kemudian diriung (dimakan bersama atau dibawa pulang) setelah melakukan doa bersama.

\section{Bulan Sili Mulud}

Bulan Sili Mulud atau lebih dikenal dengan bulan Rabiul Akhir diperingati sebagai hari kelahiran Siti Fatimah binti Muhammad SAW. Di Ciomas, acara ini biasanya dilakukan kecil-kecilan oleh para ibu pengajian. Masing-masing ibu pengajian membawa pipiti atau cecepon kecil (wadah untuk membawa nasi dan makanan lain) yang dibawa ke madrasah atau ke majlis ta'lim. Makanan itu kemudian dikumpulkan dan didoakan oleh kiai atau ustadz (laki-laki) sebelum dimakan atau diriung bersama.

\section{Bulan Rajab}

Bulan Rajab dikenal sebagai peringatan Isra Mi'raj Nabi Muhammad SAW yang dilakukan pada tanggal 27 Rajab. Untuk memperingati Isra Mi'raj ini, warga Ciomas membuat makanan yang akan diriung bersama di musholla atau masjid. Selain riungan bersama, setiap tahun masyarakat Ciomas melakukan pengajian kitab Dardir (sebuah kitab berisi sejarah perjalan Nabi Muhammad dalam Isra Mi'raj). Pengajian ini dilakukan pada malam hari tanggal 27 Rajab, dari jam 8 malam sampai jam 3 atau jam 4 dini hari.

7. Bulan Rowah

Bulan Rowah diperingati sebagai peristiwa atau slametan pergantian buku atau catatan amal manusia. Pada bulan inilah, Allah menutup catatan lama amal manusia, dan menggantinya dengan catatan yang baru. Untuk memperingati acara ini, warga Ciomas melakukan slametan dan riungan biasa di musholla yang biasanya dilakukan antara tanggal 12 Rowah sampai dengan tanggal 25 Rowah.

\section{Bulan Puasa}

Bulan puasa atau bulan Romadhan adalah bulan suci dimana seluruh umat Muslim diwajibkan untuk berpuasa selama satu bulan penuh. Untuk memperingati bulan Puasa ini, masyarakat Ciomas biasanya melakukan Slametan Ngunut pada pertengahan bulan Ramadhan. Shalat tarawih yang diakhiri dengan shalat witir pun biasanya disertai dengan doa Qunut sejak malam tanggal 15 Ramadhan. Acara riungan pun dilakukan pada malam hari tanggal 15 Ramadhan, biasanya dilakukan setelah shalat Taraweh berjama'ah. 


\section{Bulan Syawal}

Bulan Syawal, tepatnya tanggal 1 Syawal, merupakan hari kemenangan bagi Umat Islam di seluruh dunia yang sudah menjalani peperangan hawa nafsu, berpuasa selama satu bulan penuh. Di Ciomas, untuk memperingati Hari Raya Idul Fitri ini, masyarakat tidak hanya melakukan shalat sunat berjamaah di pagi hari, tapi juga melakukan silaturahmi kepada keluarga dan kerabat, juga melakukan ziarah. Berbagai jenis makanan dan kue-kue juga disediakan oleh warga.

10. Bulan Haji

Pada bulan Haji, masyarakat Muslim di seluruh dunia memperingati Hari Raya Idul Adha atau Hari Raya Kurban, tepatnya dari tanggal 10-13 bulan Haji. Sama halnya dengan lebaran Idul Fitri, warga Ciomas juga melakukan ritual dan aktifitas yang sama sebagaimana dalam Hari Raya Idul Fitri.

Dari penjelasan di atas, nampak beragam ritual sosial keagamaan yang ada pada masyarakat Ciomas merupakan salah satu bentuk mereka dalam mengagungkan dan menghormati agama mereka, secara khusus melambangkan rasa syukur mereka kepada Tuhan. Ritual sosial keagamaan yang mereka lakukan merupakan ekspresi keagamaan yang muncul karena adanya kesadaran bahwa mereka adalah bagian dari makhluk sekaligus bagian dari masyarakat sosial yang perlu terlibat dan berpartisipasi dalam berbagai kegiatan sosial keagamaan yang menjadi tradisi dan budaya mereka.

Agus berpendapat bahwa kepercayaan kepada yang sakral dan supranatural menuntut ia diperlakukan secara khusus. Oleh karena itu, ada beragam tata cara perlakuan terhadap yang sesuatu yang disakralkan. Seringkali upacara, persembahan, sesajen, dan beragam bentuk ritual lainnya tidak dapat dipahami secara ekonomis, rasional, dan pragmatisnya. Ia dilakukan sebagai upaya membujuk yang dianggap sakral dan gaib tersebut agar mau memenuhi kebutuhan pragmatisnya. Karena sesuatu yang dipercayai sebagai hal yang sakral, maka perlakuan terhadapnya tidak boleh seperti terhadap benda biasa, terhadap yang profane. Ada tata tertib tertentu yang harus dilakukan dan ada juga larangan atau pantangan yang harus dihindari (Agus, 2005: 98).

Gagalnya atau ketidakhadiran kita dalam sebuah kegiatan ritual akan dianggap sebagai bentuk ketidaksopanan kita, dan kita akan dianggap aneh dan asing oleh masyarakat kita. Dalam hal ini, definisi dasar dari sebuah ritual adalah bahwa ritual itu merupakan tindakan-tindakan yang dilakukan lebih dari sekedar tujuan mereka yang bermanfaat saja (Nye, 1988: 133-134). Artinya bahwa ritual merupakan tindakan-tindakan yang memiliki makna jauh dibalik 
tindakan-tindakan ritual itu sendiri. Jadi secara singkat ritual itu dimaknai sebagai tindakan-tindakan yang bermanfaat.

Edmund Leach, sebagaimana dikutip oleh Eller (2007:110), dalam hal ini mendefinisikan ritual sebagai perilaku yang membentuk sebagian sistem tanda dan yang bertugas untuk mengkomunikasikan informasi. Catherine Bell dalam bukunya Ritual Theory, Ritual Practice, berpendapat bahwa ritualisasi merupaan suatu hal dari beragam strategi yang secara kultural bersifat khusus untuk mengatur beberapa aktifitas berganti dari yang lain, untuk menciptakan dan memberikan hak istimewa bagi suatu perbedaan yang bersifat kualitatif antara the sacred (yang suci) dan the profane (yang biasa), dan untuk menganggap perbedaan-perbedaan itu berasal dari pemikiran realitas manusia yang melebihi kekuatan-kekuatan manusia sebagai pelaku hidup (Bell, 1992: 74). Rappaport (1999: 24) mengartikan ritual sebagai pertunjukan serangkaian tindakan dan ungkapan formal yang kurang lebih sama, yang tidak sepenuhnya disandikan oleh pelaku.

Dari penjelasan di atas, jelas bahwa perilaku atau tindakan ritual merupakan sebuah elemen paling penting dalam kehidupan kultural masyarakat. Dalam hal ini, Malory Nye berpendapat bahwa sebagian besar perilaku ritual dilakukan secara tidak disadari dan keluar dari kebiasaan, bahkan tanpa memikirkan tentang apakah ada makna dan tujuan dibalik tindakan ritual tersebut. Kadang-kadang, menurutnya, sebenarnya keotomatisan dari tindakan ritual semacam itu yang mendorong kita menyebutnya sebagai ritual, dalam makna ritual yang tanpa dipikirkan dan tidak bermakna. Tapi, tidak semua tindakan ritual dilakukan dengan cara yang tanpa dipikirkan, beberapa ritual barangkali dilakukan secara khidmat dan khusyu (Nye, 1988: 132). Ritual keagamaan ini juga menunjukkan adanya keinginan masyarakat Ciomas untuk menjaga identitas kultural mereka sebagai masyarakat yang religius.

\section{Tradisi Slametan pada Ritus Peralihan}

Manusia terus mengalami perkembangan selama hidupnya, dari mulai bayi, anak-anak, remaja, dewasa, orang tua, dan selanjutnya akan mengalami kematian. Di beberapa daerah seperti di Kabupaten Pelalawan Provinsi Riau (Hidayat, 2009), di Batak Toba-Tapanuli Utara (Simandjuntak, 1993), di Madura (Djojomartono, 1993; Munir 1993), di Jawa (Sulaiman, 1993), di Minangkabau (Abdullah, 1993), dan Bali (Dhari, 1993), untuk memperingati masa-masa peralihan dari bayi ke remaja, dari remaja ke dewasa, dan seterusnya seringkali diadakan ritual-ritual, upacara-upacara, maupun beragam slametan 
sebagai penanda atau simbol bahwa manusia adalah makhluk yang selalu berubah; berubah tidak hanya dalam arti fisik, tetapi juga dalam kepribadian dan kematangan mental.

Di daerah Ciomas, sebagian besar masyarakatnya masih melakukan beragam tradisi slametan untuk mengisi dan memperingati masa-masa peralihan tersebut. Ritual-ritual slametan ini tidak hanya dilakukan oleh keluarga inti, tetapi melibatkan anggota masyarakat yang lain, terutama kerabat atau tetangga terdekat, karena dalam tradisi slametan ini ada upacara komunal (biasanya dalam bentuk riungan diiringi dengan membaca doa-doa atau wirid-wirid tertentu) yang dilakukan bersama-sama pada waktu tertentu.

Berikut adalah beberapa tradisi slametan dalam ritus-ritus peralihan yang masih dilakukan oleh sebagian besar masyarakat Ciomas:

1. Ritual slametan pada masa kehamilan

Di daerah Ciomas, perempuan yang sudah menikah dan sedang hamil anak pertama umumnya melakukan tradisi selametan 'mitung bulan' atau 'rurujakan' pada masa kehamilan menginjak usia tujuh bulan. Mereka masak berbagai jenis makanan, baik nasi, lauk pauk, sayuran, dan berbagai jenis kue. Dari beragam jenis makanan yang disediakan, ada satu jenis makanan yang wajib ada dalam acara rurujakan ini, yaitu rujak.

2. Ritual slametan pada masa melahirkan

Seorang bayi yang baru lahir akan membawa kebahagiaan bagi keluarganya. Untuk menyambut bayi yang baru lahir, masyarakat Ciomas biasanya akan melakukan ritual slametan suguh tamu tepat pada hari dimana bayi itu lahir, atau kalau lahirnya malam, acara suguh tamu dilakukan pada pagi harinya. Berbeda dengan acara nujuh bulanan, slametan suguh tamu ini umumnya diadakan secara sederhana dan ala kadarnya dengan mengundang sekitar 10-15 orang tetangga dekat. Selanjutnya, setelah bayi berusia 7-40 hari, akan ada acara slametan lainnya, yaitu cukuran atau aqikahan.

3. Ritual slametan khitanan

Di Ciomas, untuk bayi perempuan, pada saat slametan cukuran, biasanya juga dilakukan ritual sunatan. Bayi perempuan, menurut sebagian masyarakat Ciomas, sebaiknya disunat pada usia 7 hari-40 hari, maksimal sampai usia bayi 7 bulan dan dilakukan dengan acara yang sangat sederahana tanpa riungan. Untuk sunatan anak laki-laki, biasanya dilakukan pada usia 2-10 tahun. Berbeda dengan sunatan anak perempuan, slametan untuk sunatan anak laki-laki seringkali dilakukan besar-besaran. 
4. Ritual slametan masa pubertas bagi remaja perempuan

Anak perempuan yang menginjak usia remaja dan ditandai dengan menstruasi pertama juga biasanya diberikan ritual slametan. Slametan ini, bagi masyarakat Ciomas, disebut dengan slametan kekelepon. Nama kekelepon ini sesuai dengan nama kue yang dibuat untuk menandakan masa haid pertama bagi remaja perempuan. Kue ini selanjutnya dibagi-bagikan kepada para tetangga setelah dibacakan doa.

5. Ritual slametan pada masa perkawinan

Upacara perkawinan adalah ritual slametan paling besar-besaran bagi masyarakat Ciomas dibandingkan dengan ritual slametan lainnya. Ada banyak orang yang terlibat dalam upacara ini. Semakin besar dan meriah serta semakin banyak tamu yang hadir dalam acara ini, semakin nampak status sosial dari orang yang memiliki hajat. Setelah akad nikah, seringkali ada ritual ayunan atau saweran oleh seorang praktisi ayunan, sementara kedua mempelai duduk di tenda (puade) yang disediakan untuk kedua mempelai. Kadang-kadang juga dilakukan ritual pembacaan degung oleh seorang praktisi (Masitoh, 2011).

6. Ritual slametan untuk membangun dan mengisi rumah baru

Membuat atau mengisi rumah baru bagi masyarakat Ciomas perlu menyelenggarakan sebuah ritual slametan tertentu agar rumah tersebut membawa keberkahan juga membawa keselamatan bagi penghuninya nanti. Untuk mengisi rumah baru, ritualnya disebut juga dengan ngaruwat umah yang umumnya diselenggarakan secara sederhana, dengan mengundang beberapa tetangga untk melakukan riungan dan membaca Surat Yaa-siin. Sementara itu, untuk membuat rumah baru atau sebelum peletakan batu pertama seringkali diadakan slametan Munar. Dalam ritual slametan ini dibacakan 'syaikh' atau 'wawacan syaikh' oleh seorang praktisi (Saip, 2011).

7. Ritual slametan pada upacara kematian

Untuk memperingati acara kematian ini, ada berbagai ritual slametan yang dilakukan oleh masyarakat Ciomas. Tahlilan adalah ritual do'a yang dilakukan untuk si mayit dari malam ke-1 sampai malam ke-7 yang biasanya dlakukan setiap ba'da maghrib atau ba'da 'Isya. Selanjutnya, nelung dina, mitung dina, matang puluh dina,nyatus dina, yang dilakukan untuk memperingati hari ke-3, ke-7, ke-40, ke-100 hari paska kematian. Setelah acara nyatus dina selesai, ritual slametan kematian berhenti, baru dilakukan lagi setiap setahun sekali pada hari dimana si mayit meninggal, atau disebut juga dengan khaul atau kirim doa.

el Harakah Vol.17 No.2 Tahun 2015 
Dari berbagai ritual slametan masyarakat Ciomas di atas, nampak bahwa setiap fase peralihan hidup manusia memiliki arti dan makna penting bagi masyarakat Ciomas. Beragam aktifitas slametan tersebut menunjukkan adanya keyakinan sekaligus kesadaran dalam alam pikiran masyarakat Ciomas bahwa hidup manusia akan selalu mengalami perubahan dan pergantian dari satu fase ke fase yang lain yang satu sama lain saling saling memiliki keterkaitan. Oleh karena pentingnya tiap-tiap fase peralihan manusia ini, masyarakat melakukan aktifitas religi, yakni slametan, sebagai simbol komunikasi antara manusia dengan Tuhan atau makhluk gaib tertentu di mana manusia sebagai makhluk yang lemah memohon bantuan Tuhan atau ruh-ruh tertentu untuk dapat memberikan perlindungan dan keselamatan bagi manusia pada tiap masa peralihan. Upacara slametan ini sendiri sebenarnya merupakan pusat dari sistem upacara religi dalam agama Kejawen dalam masyarakat Jawa, yang sebenarnya tidak didapati dalam ajaran agama Islam yang murni. Ritual ini merupakan tradisi atau budaya lokal yang sudah mengalami penyesuaian dan pencampuran antara unsur-unsur Hindu-Jawa dengan Islam (Sulaiman, 1993: 101-102).

Berbagai ritual slametan dalam masa peralihan (rites de passage) sebenarnya tidak hanya ditemui pada masyarakat Ciomas Banten. Fenomena ini juga terjadi di banyak tempat di seluruh dunia. Nampaknya, manusia dari banyak kebudayaan percaya bahwa dalam setiap masa peralihan hidup manusia akan selalu ada suasanan berbahaya yang ditemui. Untuk menolak bahaya tersebut, manusia melakukan upaya untuk menyelamatkan diri dengan cara melakukan upacara-upacara atau ritual-ritual baik yang dilakukan secara individual maupun secara kolektif. Menurut beberapa antropolog upacara tersebut berfungsi sebagai sarana pengumuman kepada khalayak ramai tentang tingkatan hidup yang telah dicapai oleh seseorang (Koentjaraningrat, 1980: 89-90).

\section{Simpulan}

Berbagai ritual keagamaan dan ritual slametan masyarakat Ciomas di atas nampaknya merupakan bagian dari upacara religi yang mengandung makna yang lebih dari sekedar meminta keselamatan atau mengagungkan Tuhan atau Nabi. Jika diamati fungsi dan makna religi yang terkandung dalam beragam ritual keagamaan dan ritual slametan yang dilakukan oleh masyarakat Ciomas, nampak bahwa ritual-ritual tersebut menunjukkan adanya fungsi-fungsi sosial yang dapat merekatkan nilai solidaritas antar anggota masyarakat. Di samping itu, ritual-ritual tersebut juga dapat dimaknai sebagai simbol komunikasi, 
sekaligus penghormatan manusia secara kolektif terhadap Tuhan dan makhluk-makhluk gaib lainnya yang dipandang memiliki kekuatan luar biasa yang dapat menjamin keberlangsungan hidup masyarakat. Ritual-ritual itu dapat juga dimaknai sebagai 'bujukan' atau 'rayuan' manusia kepada Tuhan atau makhluk-makhluk gaib tertentu agar dapat memberikan perlindungan, keselamatan, sekaligus juga berkah kepada masyarakat setempat.

\section{Daftar Pustaka}

Abdullah, Sjafrida. 1993. "Adat Istiadat perkawinan di Minangkabau." Pp. 147-173 dalam Ritus Peralihan di Indonesia. Jakarta: Balai Pustaka.

Agus, Bustanudin. 2006. Agama dalam Kehidupan Manusia: Pengantar Antropologi Agama. Jakarta: PT Raja Grafindo Persada.

Ali, Mufti. 2012. Pengaruh Geger Cilegon 1888 terhadap Perkembangan Pesantren di Banten Masa Kolonial. Serang: Lemlit IAIN SMH Banten.

Bell, Catherine. 1992. Ritual Theory, Ritual Practice. Oxford: Oxford University Press

Bruinessen, Martin van. 1995. Kitab Kuning, Pesantren dan Tarekat: TradisiTradisi Islam di Indonesia. Bandung: Mizan.

Dhari, Mas Aboe. 1993. “Upacara Ngaben di Bali.” Pp. 241-270 dalam Ritus Peralihan di Indonesia. Jakarta: Balai Pustaka.

Djojomartono, Muljono. 1993. "Adat Istiadat sekitar Kelahiran pada Masyarakat Nelayan di Madura.” Pp. 71-100 dalam Ritus Peralihan di Indonesia. Jakarta: Balai Pustaka.

Eliade, Mircea. 1974. The Myth of the Eternal Return or, Cosmos and History. Terj. willard R. Trask. New York: Princeton University Press $\backslash \backslash$

Eller, Jack David. 2007. Introducing Anthropology of Religion. Culture to the Ultimate. New York, London: Routledge.

Endraswara, Suwardi. 2003. Mistik Kejawen. Sinkretisme, Simbolisme dan Sufisme dalam Budaya Spiritual Jawa. Yogyakarta: Narasi.

Fischer, H.TH. 1980. Pengantar Antropologi Kebudayaan Indonesia. terj. Anas Makruf. Jakarta: Pustaka Sarjana P.T. Pembangunan. 
Geertz, Clifford. 1960. The Religion of Java. New York: The Free Press of Glencoe.

Hakim, Lukman. 2006. Banten dalam Perjalanan Jurnalistik. Pandeglang: Banten Heritage

Harsojo. 1984. Pengantar Antropologi,cet ke-5. Jakarta: Binacipta.

Hidayat. 2009. Akulturasi Islam dan Budaya Melayu. Studi tentang Ritus Siklus Kehidupan Orang Melayu di Pelalawan Provinsi Riau. Jakarta: Badan Litbang dan Diklat Departemen Agama RI.

Humaeni, Ayatullah. 2009. "The Phenomenon of Magisc in Banten Society." MA Thesis, unpublished, Leiden University, the Netherlands. 2009. Penggunaan Magis dalam Proses Pemilihan Kepala Desa di Banten. (Studi di Kecamatan Ciomas dan Kecamatan Padarincang, Serang, Banten). Serang: Lembaga Penelitian IAIN "SMH” Banten.

Hurgronje, C. Snouck. 2006. Mekka In The Latter Part of the 19th Century: Daily Life, Customs and Learning The Moslims of the East-Indian-Archipelago. Leiden: Late E.J. Brill.

Koentjaraningrat. 1963. "Review: The Religion of Java, Clifford Geertz". Pp. 188-191 dalam Majalah Ilmu-Ilmu Sastra Indonesia, I. 1980. Sejarah Teori Antropologi 1. Jakarta: UI Press. . 2002. Pengantar Ilmu Antropologi, cet.ke-8. Jakarta: Rineka Cipta.

Kusumohamidjojo, Budiono. 2010. Filsafat Kebudayaan. Proses Realisasi Manusia, cet.ke-2. Yogyakarta: Jalasutra.

Lubis, Nina H. 2004. Banten dalam Pergumulan Sejarah. Sultan, Ulama, Jawara. Jakarta: LP3ES.

. 2006. Sejarah Kabupaten Lebak. Lebak: Pemerintah Kabupaten Lebak bekerja sama dengan Pusat Penelitian Kemasyarakatan dan Kebudayaan, Lembaga Penelitian Universitas Padjajaran.

Madjid, Nurcholis. 2000. Islam Agama Peradaban. Membangun Makna dan Relevansi Doktrin Islam dalam Sejarah. Jakarta: Paramadina.

Malinowski, Bronislaw. 1955. Magisc, Science, and Religion. Garden City, N.Y.: 
Doubleday \& Company, INC.

Mansur, Khatib. 2000. Profil Haji Tubagus Chasan Sochib beserta Komentar 100 Tokoh Masyarakat Seputar Pendekar Banten. Jakarta: Pustaka Antara Utama.

Michrob, Halwani dan A. Mudjahid Chudari. 2011. Catatan Masa Lalu Banten, ed.IV. Serang: Dinas Budaya dan Pariwisata Provinsi Banten.

Mulkhan, Abdul Munir. 2000. Islam Murni dalam Masyarakat Petani. Yogyakarta: Bentang.

Munir, Mochamad. 1993. "Adat Istiadat yang Berhubungan dengan Upacara dan Ritus Kematian di Madura.” Pp. 222-238 dalam Ritus Peralihan di Indonesia, Jakarta: Balai Pustaka.

Nye, Malory. 1988. Religion The Basics, $2^{\text {nd }}$. London, New York: Routledge.

O'Keefe, Daniel L. 1982. Stolen Lightning: the Social Theory of Magisc. New York: Continuum.

Pritchard, E.E. Evans. 1984. Teori-Teori tentang Agama Primitif. Yogyakarta: PLP2M.

Radam, Noerid Haloei. 2001. Religi Orang Bukit. Yogyakarta: Semesta.

Rappaport, Roy. 1999. Religion and Ritual in the Making of Humanity. Cambridge: Cambridge University Press.

Simandjuntak, B.A. 1993. "Upacara sekitar Kelahiran pada Orang Batak Toba." Pp. 49-70 dalam Ritus Peralihan di Indonesia. Jakarta: Balai Pustaka.

Solikhin, Oman \& Akhmad Supriyatna. 2003. Golok Ciomas. Hikayat dan Keistimewaannya. Serang: Spora Pustaka.

Spencer, Herbert. 1876. The Principles of Sociology. London: Williams \& Norgate.

Sulaiman. 1993. "Upacara Tedhak Siten di Jawa." Pp. 101-107 dalam Ritus Peralihan di Indonesia. Jakarta: Balai Pustaka.

Susanto, P.S. Hary. 1987. Mitos menurut Pemikiran Mircea Eliade. Yogyakarta: Kanisius. 
Sutiyono. 2010. Benturan Budaya Islam: Puritan dan Sinkretis. Jakarta: Kompas.

Suyono, Capt. R.P. 2009. Dunia Mistik Orang Jawa. Roh, Ritual, Benda Magis, Cet. Ke-3. Yogyakarta: LKiS.

Tihami, M.A. 1992. Kiyai dan Jawara di Banten. Studi tentang Agama, Magis, dan Kepemimpinan di Desa Pasanggrahan, Serang, Banten. MA Tesis. unpublished. Jakarta: Universitas Indonesia.

Tjandrasasmita, Uka. 2011. Banten Abad XV-XXI. Pencapaian Gemilang, Penorehan Menjelang. Jakarta: Puslitbang Lektur dan Khazanah Keagamaan, Badan Litbang dan Diklat Kementerian Agama RI.

, et al. 1999. "Mengenal Peninggalan Sejarah dan Purbakala Kota Banten Lama.” Pp. 72-234, dalam Banten Menuju Masa Depan. Cilegon: Yayasan Kiai Haji Wasid.

\section{Wawancara:}

Wawanca dengan Ibu Adlah, seorang dukun beranak/dukun bayi, 61 thn, di Kp.Sawah, Ciomas, Serang Banten, 7 Oktober 2011.

Wawanca dengan Ibu Masitoh, 41 thn, perias pengantin, di Kp.Sawah, Ciomas, Serang Banten, 11 Oktober 2011

Wawancara dengan Ust. Rohman, (42 thn), pimpinan pesantren Daarul Istiqomah, Kp. Sawah, Desa Ciomas, Serang, Banten, 28 Agustus 2011

Wawancara dengan Ai, 39 thn, seorang dukun, di Desa Ciomas, Serang, Banten, 30 Juli 2011

Wawancara dengan Bpk. Saip, 53 thn, pedagang, Kp.Cempaka, Ds. Ciomas, Serang Banten, 11 Oktober 2011

Wawancara dengan Bpk.H.Ry, Kp.Sawah, Desa Ciomas, 21 Oktober 2011

Wawancara dengan Fauziah, 38 thn, seorang pedagang keliling, di Desa Ciomas, Serang Banten, 12 September 2011.

Wawancara dengan H. Juhdi Mansur, 65 thn, seorang pensiunan pegawai 
KUA, di desa Ciomas, Serang, Banten, 12 September 2011

Wawancara dengan Ibu Een, 45 thn, Ibu Rumah Tangga, di Desa Ciomas, Serang, Banten, 12 September 2011

Wawancara dengan Ibu Hj.Slk, 60 thn, Ibu rumah tangga, di Barugbug Ciomas Serang Banten, 15 September 2010.

Wawancara dengan Ibu Suntiwari, 50 thn, guru agama di Madrasah Diniyah Al-Halimy, Kp. Masigit, Desa Ciomas, Serang Banten, wawancara 7 September 2011

Wawancara dengan Idhom, 52 thn, di Ciomas, Serang, Banten, 1 November 2011

Wawancara dengan K.H. J.M, seorang pimpinan pesantren di Padarincang, Serang, Banten, 16 Oktober 2010

Wawancara dengan K.H. Maksum, (57 tahun), seorang kyai karismatik di Desa Ciomas, Serang, Banten, 20 Oktober 2011.

Wawancara dengan K.H.Anas Al-Bandanidji, (60 thn), seorang kyai di Desa Ciomas, Serang, Banten, tanggal 28 Oktober 2011.

Wawancara dengan K.H.F., seorang kyai hikmah di Desa Babakan, Ciomas, Serang Banten, 30 September 2011

Wawancara dengan Mashadi, (31 thn), seorang santri di Pesantren Al-Halimy, di Desa Ciomas, Serang, Banten, tanggal 28 Oktober 2011

Wawancara dengan Subki (53 thn), seorang pedagang, di Kp. Masigit, Desa Ciomas, Serang Banten, 2 Oktober 2011.

Wawancara dengan Tati, 35 thn, Ibu Rumah Tangga di Desa Ciomas, Serang, Banten, 3 Oktober 2011

Wawancara dengan Ust. Sujud, 48 tahun, seorang guru ngaji di Ciomas, Serang Banten, 15 Agustus 2010.

Wawancara dengan Zainuri, 63 thn, seorang petani di Desa Ciomas, Serang, Banten, 29 Juli 2011 